\title{
NON-CHRISTIAN MILITARY CEMETERIES OF GALICIA
}

(C) Stasyuk O., 2020

The article analyzes the Jewish and Muslim military cemeteries found in Galicia, their history, species, forms, and state of preservation. Preventive measures have been proposed to preserve historic non-Christian military cemeteries

Key words: military cemetery, memorial sculpture, restoration, stone.

\section{Formulation of the problem}

Historic cemeteries are an integral part of the cultural landscape of every city or town, evidence of the ideology and spiritual life of their time. Military cemeteries may not be in every settlement, but they record their time, history, ideology and extremely important moments for the country and society very clearly. The first military cemeteries appeared in Galicia during the First World War. And on the eve of the First World War there was no tradition of national honoring the great victims of war. The military cemeteries of the First World War were important memorial sites of this conflict. The Jews were citizens of the Austrian state and it was their duty to serve in the army. The Turkish military as allies took part in hostilities on the Galician front. This is one of the features of the military cemeteries of Galicia.

Regardless of the status of the cemetery, there are no facilities in Ukraine in absolutely perfect condition. Each cemetery requires constant care and order. The ideological component is constantly superimposed on military cemeteries, which complicates their existence.

And today we have a war in our state again. And we are already facing the problem of military cemeteries, which we will have to solve. At the same time, it is necessary to consider ways to preserve historical military cemeteries, their designation, as well as their ways of existence in the historical memory of the people and the state.

\section{Analysis of recent research and publications}

Beginning in the 1990s, people in Ukraine became interested in and wrote about historic cemeteries. They mainly researched the history of the origin and functioning of the cemetery and described prominent people buried in these cemeteries. Mostly addressed to the famous cemeteries in large cities. In Lviv, almost all cemeteries, both existing and non-existent, are described. In particular, such Lviv researchers as Pavlo Grankin (Grankin, 1999), Khrystyna Kharchuk (Kharchuk, 1999) described Austrian military burials in Yaniv and Lychakiv cemeteries. Materials on World War I military cemeteries can also be found in books on the Austrian army, or simply on the military monuments of A. Płomieńczyk (Płomieńczyk 1916) and A. Borg (Borg, 1991).

The topic of the history of the Jewish community in Lviv is widely researched. We are talking about events, famous people, cultural monuments, including the cemetery. Researchers such as M. 
Bałaban (Bałaban, 1909) and J. Schall (Schall, 1934) studied this topic. These materials are extremely valuable because as for the Jewish community in Lviv, very few material monuments have been preserved. In our time, the Jewish necropolis in Lviv was described in particular by J. Helston (Helston, 1998).

As for the Islamic - in our case, Turkish burials in Galicia, here we draw information from historians' research on the Turks at the front in Galicia, or on the Turkish army in general. This is the research of Igor Andrushko (Andrushko, 2016) or Edward Erickson (Erickson, 2001). Then there is information from journalists about the restoration of Turkish cemeteries or the arrival of high-ranking Turkish guests to honor the memory of their compatriots who died on the fronts of World War I.

Agnieszka Partridge's book (Partridge, 2005) is an extremely voluminous and very comprehensive book on Galician military burials during the First World War. The book is richly illustrated with both historical and modern photographs, which greatly expands the informativeness.

\section{The purpose of the article}

The purpose of the article is to analyze the history of the origin and formation of Jewish and Muslim military cemeteries in Galicia. Use specific examples To show the main problems of preservation that occur in non-Christian military cemeteries in Galicia using specific examples. And offer options for preventive action to maximize the preservation of existing Muslim and Jewish military cemeteries, as well as a number of measures to preserve the memory of non-existent military cemeteries.

\section{Presentation of the main material}

Let's see how the fallen soldiers were treated in the past. It was the ancient world that formed the ethos of the hero who gave the most valuable thing for the homeland - his life. As well as the ethos of the loser, who was to be buried with respect worthy of each person.

In Christian Europe, fallen soldiers were buried directly on the battlefield. There was often a truce after the battle to clear the battlefield. Just as in ancient times, mass graves were prepared over which mounds were poured from the ground. Prominent and titular knights found their last rest in churches or family chapels. Ordinary soldiers remained anonymous.

During the Enlightenment, the responsibility for caring for the grave passed from the church to society and the family. The changes concerned the approach to the dead in general and to the fallen heroes in particular. Attitudes toward soldier anonymity have changed. The first soldiers to die in the memorial were soldiers killed in the French Revolutionary War. Soldiers' monuments were erected in Lucerne and in Paris. It is then that the idea of symbolic homage to the heroes in the form of the tomb of an unknown soldier arises. In Western Europe, chapels and ossariums containing the remains of the dead were built on the battlefields. At the same time, the mound as a form of common grave, as well as a memorial structure remained one of the most popular forms of commemorating the dead, as noted by the English researcher A. Borg (Borg 1991).

Until the First World War, no military cemeteries were built in Europe. It was World War I that provoked the need to build military cemeteries in our latitude. During this war, soldiers died in unprecedented numbers. The war affected everyone. Newspapers wrote widely about her, eyewitnesses told. There was no family that did not suffer losses during this war. In many countries, there is a need to honor the dead. There have been publications on ethical, aesthetic and architectural issues related to the design of military cemeteries. In order to avoid conflicts over how to honor the dead, as noted in his book A. Partridge (Partridge, 2005) for the construction and appearance of 
military cemeteries in France, Germany and Austria-Hungary were responsible to the relevant military authorities. In each of the states, directives were formulated based on cultural traditions, respect for the dead and cultivating the memory of them. It is noted that each soldier should be identified, if possible, should have his own nameplate, everyone has the right to receive a tombstone in the form of which will speak of religious affiliation and military rank. The same principles applied to the burial of fallen enemies.

These noble intentions were realized differently on the western and eastern fronts. On the Western Front, this was due to incomparably greater military losses and different approaches to the military affiliation of the dead. The ordering of the battlefields, the exhumations of the dead and the construction of cemeteries began several years after the end of the war.

Military cemeteries in Galicia were established during the hostilities in 1914-1918. In a situation of material crisis and general uncertainty about the further results of the war. It was planned that these burials would become a kind of propaganda, consolidating the peoples and societies around the Habsburg throne. They were to become material evidence of the state's care for those who did not return home.

It should be noted here that the Turkish military took part in the fighting on the Galician front. They proved to be brave warriors, although their losses were very great. Many Turks wounded in battle died in hospitals in Lviv, Krakow and Vienna, according to Ihor Andrushko (Andrushko, 2016 ) in his study. This is one of the features of Galicia military cemeteries.

In June 1916, an agreement was reached between the Turkish and Austrian general staffs, according to which the 15th Corps of the Turkish Army left for Galicia. The corps consisted of two divisions and numbered about 40,000 soldiers and officers. Turkish troops received a section of the front along the Golden Linden River southwest of Brzezany. Organizationally, the Turkish units were subordinated to the headquarters of the Southern Army of Austria-Hungary. Turkish troops began to take part in the fighting on August 19. The Turks spent the winter relatively quietly in the trenches above the Golden Linden, and after the revolution took place in Russia in February 1917, the fighting stopped altogether. Due to the fact that active hostilities in Galicia ceased, the command decided to withdraw the 15th Corps home. The Turks began to leave and then suddenly began a major Russian offensive. Turkish troops still managed to take part in the general Austro-German offensive, which was a response to the "Kerensky offensive". Overcoming the resistance of Baron Wrangel's Russian cavalry, the Turks reached almost Zbruch. And on August 22, 1917, the last Turkish units left Galicia. And Turkish cemeteries remained in Galicia. Turkish burials are located in the modern Ivano-Frankivsk, Ternopil and Lviv regions. Many Turkish burials were destroyed by the Soviet authorities in 1948-1949.

During the First World War, at the request of the Russian authorities, the President of Lviv, Tadeusz Rutowski, allocated land near the Lychakiv Cemetery for a cemetery for Austrian prisoners of war who died in Lviv hospitals. After the Austrians returned to Lviv, the newly created cemetery was transferred to the military inspection of cemeteries and became the basis for the burial of fallen soldiers of the Austrian and Allied armies: German and Turkish, as noted by Lviv researcher P. Grankin (Grankin P. 1999). Initially, the Austrian military cemetery was surrounded by a low wooden fence. Crosses or tombstones were also made of wood, each with a grave number and a table with the name on it. A more detailed plan of this cemetery is the plan of 1927. In this plan, the Arabic numerals indicate 4712 individual and common graves. A separate group consisted of the burials of Turkish soldiers who served in the Austrian army and were buried near the cemetery wall. There were stone pillars on their graves with inscriptions ending in friezes at the top. 
In archival photos of the early twentieth century. we see a general view of the military cemetery. The white crosses of the soldiers of the Austrian army, and the burials marked by dark monuments in the left corner are obviously the burials of the soldiers of the Turkish army (Fig. 1). In the photo next we see a view of the cemetery from a closer distance. Burial of Turkish soldiers in the foreground (Fig. 2). Unfortunately, the size and quality of the photo do not allow you to see these memorials well - it is impossible to read what is written on them or see other symbolic signs.

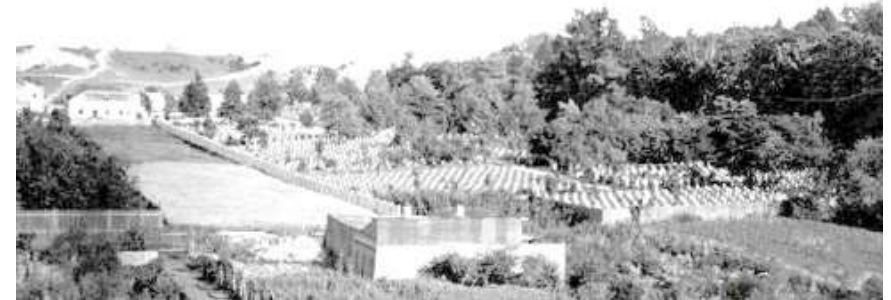

Fig. 1 Austrian military cemetery in Lychakiv.

Panoramic view.

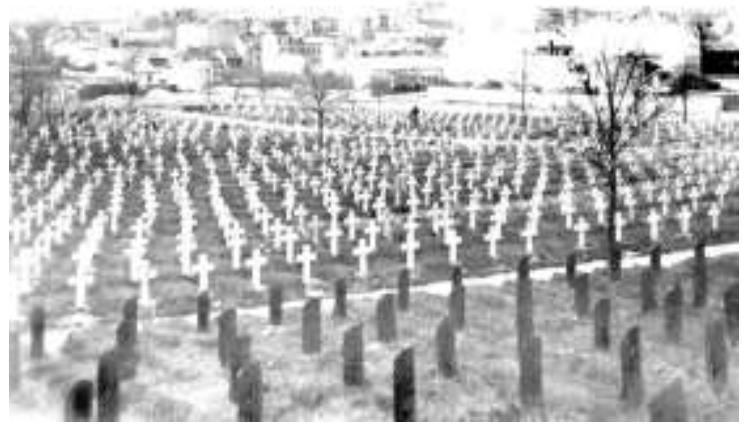

Fig. 2 Austrian military cemetery in Lychakiv. Close up photo

In 1946-1947, after their second arrival, the Bolsheviks using bulldozers razed to the ground and dug Austrian military cemetery Civil and military burials were arranged in its place. Thus was formed the 82nd field of Lychakiv cemetery, which was divided into separate sections. Thus, Turkish military burials were lost in Lviv. The surviving Turkish military cemeteries are located on the outskirts of the villages of Verkhnya Lypytsia, Lopushna, Pidvysoke, Gutysko and Mechyshchiv. Until recently, military burials also existed in Stryi, Rohatyn, Pukov and Putyatyntsi, where military hospitals were located, in which some wounded soldiers died. These soldiers were buried in local cemeteries, as noted by Ukrainian researcher I Andrushko (Andrushko, 2016). For example, in Lopushnya it is not just a cemetery, but a pantheon of polished shell rock, granite and marble. This cemetery is the last refuge of about two hundred soldiers of the Ottoman state. But in Gutysko the cemetery is special. Officers are buried here, there is also the grave of the Turkish general. A total of 80 senior officers (Fig. 3). During the Soviet era, Turkish burials were covered with tall grass and stones, leaving only small bumps and stone caps - on each grave of a Turkish officer was such a cap (Fig. 4). In the early 2000s, with the assistance of the Turkish embassy, the memorial was restored.

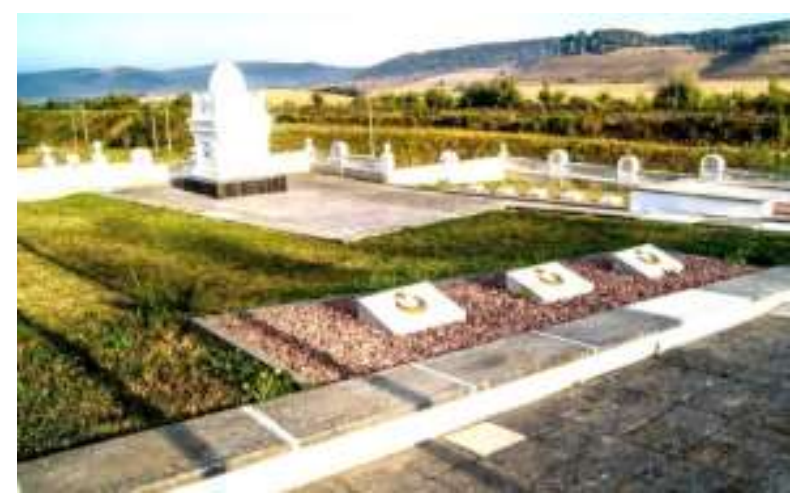

Fig. 3 Turkish military cemetery in Gutysko

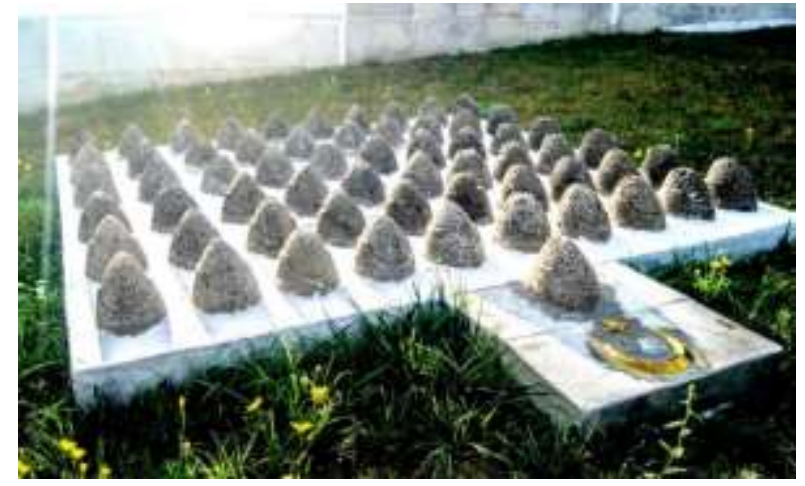

Fig. 4 Stone hats in the Turkish cemetery in Gutysko 
Jews were citizens of the Austro-Hungarian monarchy. Until 1788, in the Austro-Hungarian monarchy, the Jewish population was considered "unworthy of the defense service." As early as 1787, the People's Military Council, the predecessor of the Imperial-Royal Ministry of War, emphasized that Jews could not be called up for military service. This decree applied exclusively to Jews of the Jewish faith. However, as early as 1878, Emperor Joseph II issued an order stating that "Jews are capable of military service in the army, especially as drivers and gunners of artillery." The final settlement of matters concerning military service in the Habsburg monarchy came in 1868 when a decree on general military service was introduced. Every citizen who turned 21 was drafted into the army, as noted by J. Schall (Schall J. 1934). In 1869, Jews made up $4 \%$ of the total population of the monarchy. In 1872, there were $1.5 \%$ Jews in the Austrian army. The maximum number of Jews in the Austrian army was 3.9\% in 1902.

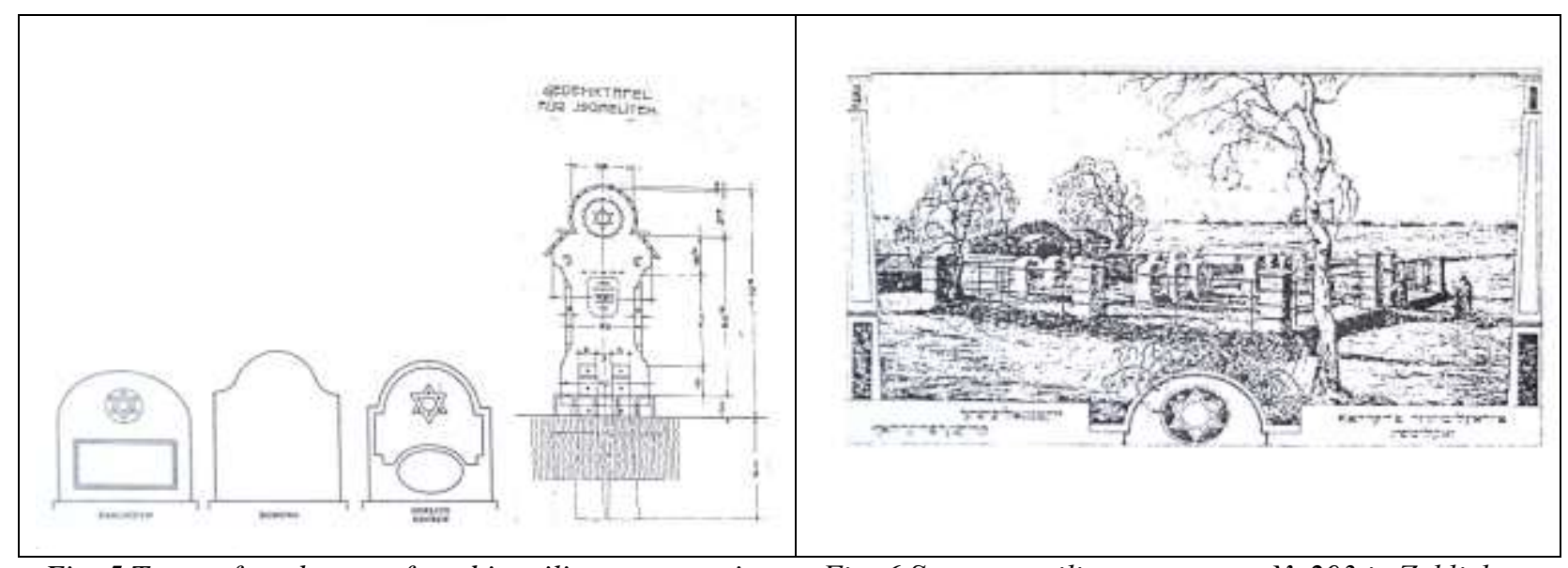

Fig. 5 Types of tombstones found in military cemeteries in Galicia

Fig. 6 Separate military cemetery № 293 in Zaklichyn. Postcard from the First World War.

In 1915-1918, as many as $10 \%$ of all officers in the Austrian army were Jews. More than 1,000 Jewish officers died on the fronts, accounting for $6.7 \%$ of all fallen officers. On the battlefields of World War I, Jewish soldiers fought and died with their comrades of other faiths and nationalities. But they were buried separately. Austrian burial law mandated the burial of Jews in separate cemeteries. The Army also adhered to this law, which we can learn from the book by A. Płomieńczyk (Płomieńczyk A. 1916).

At the end of 1915, the Department of Military Graves was established at the Ministry of War. In Galicia, military cemeteries were built by the Military Graves Departments with headquarters in Krakow, Przemyśl and Lviv. Lviv and Przemyśl were closer to the front, respectively, experiencing greater economic difficulties and uncertainty of military fate, which affected the scale of the facilities built.

The War Graves Department in Cracow designed and built 400 military cemeteries in the three years from 1915 to 1918 . Among the built cemeteries and military fields were 14 cemeteries of Jewish soldiers, which accounted for $3.5 \%$ of all built cemeteries. The burial places of Jewish soldiers in western Galicia were in Nursery, Olpini (destroyed during World War II), Bychi (destroyed during World War II), Hrybiv, Burova, Tukhiv (destroyed during World War II), Tarnów, Bresk, Zaklichyn, Bochnia, Myslenichy, and in Krakow (Fig. 5).

A common feature of Jewish military cemeteries was that most of them were built as a separate field within existing civilian cemeteries. In fact, soldiers of the Jewish faith who died on the battlefield were buried in the nearest Jewish cemetery. The only exception to this rule is a separate military cemetery № 293 in Zaklichyn (Fig. 6). It was built in 1916. Another common 
feature of Jewish military cemeteries is the simplicity and modesty of the designed projects. The artistic means used in the design of the military Jewish cemeteries were indeed extremely modest. The only architectural motif here is a tombstone in the form of a traditional matzevot made of stone or concrete. The size of the mats ranged from $60 \mathrm{~cm}$ to 2 meters. The ends of the ceilings are semicircular, oval with slightly rounded corners, etc. The only decorative element was the Star of David, except for the inscription plate (Fig. 7).

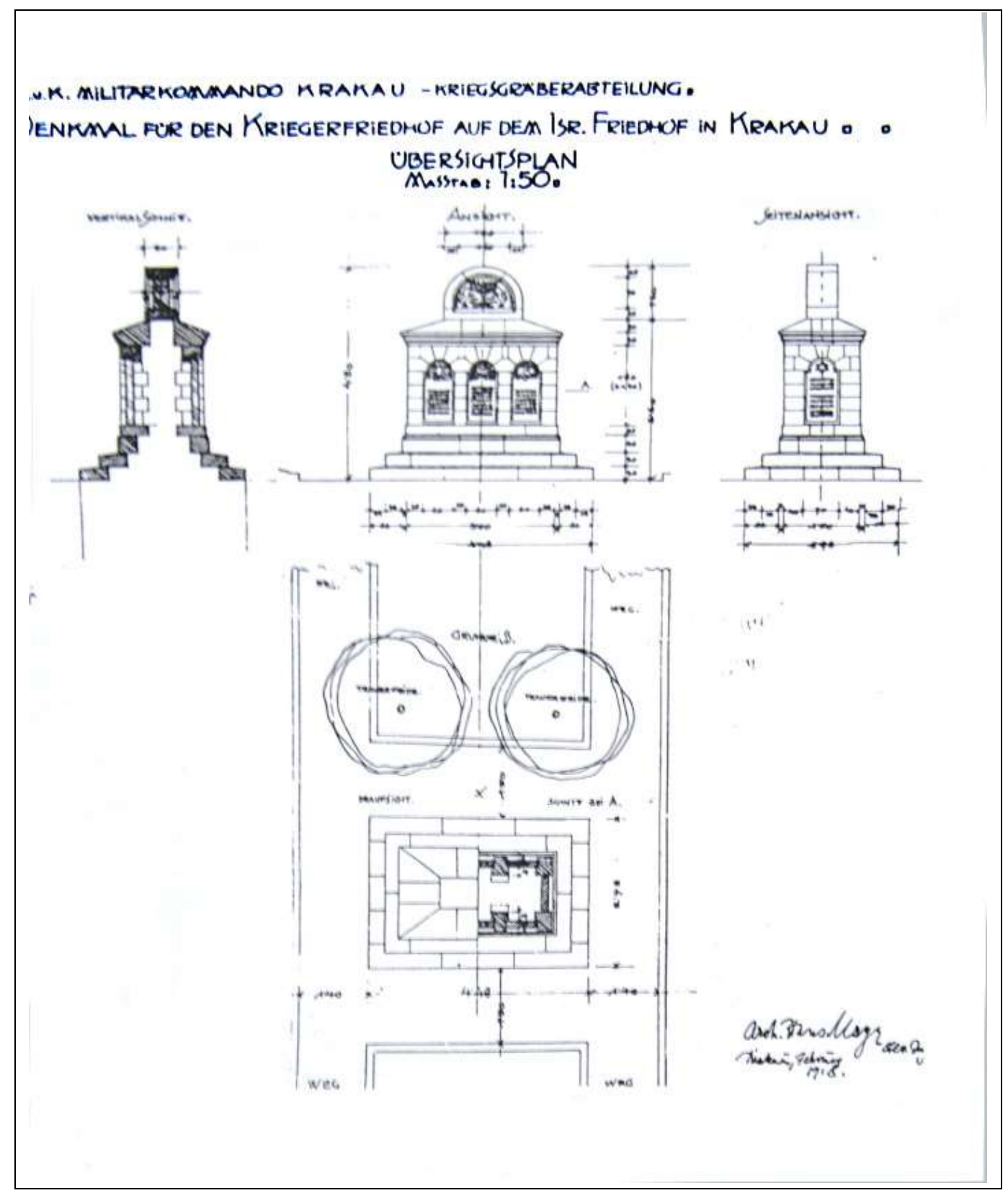

Fig. 7 Jewish military cemetery in Krakow

Drawing by Hans Mayer.

In Lviv, the oldest Jewish cemetery was the Old Jewish Cemetery, founded, according to various sources, in the late thirteenth or early fifteenth century. A new Jewish cemetery was opened in 1855. In addition, there were several small Jewish cemeteries in Lviv, founded in the mid-19th and early 20th centuries. A new Jewish cemetery was opened in August 1855 on Kortumova Hill, not far from Yanivska Street. And after 1918, a memorial to the fallen Jewish soldiers of the AustroHungarian army was erected on Mount Kortum. After the expansion of 1922, this memorial consisted of 16 rows of graves, in which there were 375 burials according to Archives (SALR, 
1922). Memorial obelisk to the fallen soldiers in the Jewish cemetery around 1919 was designed by architect Vavzhynets Daychak. Sorry, we couldn't find any images for this memorial.

Instead, a postcard from the early twentieth century was found. with the image of the Jewish military cemetery in Stryi (Fig. 8). This postcard was given to me by Olena Andronatiy, a researcher at the center ESJF in Lviv. In the photo we see the entrance gate, fence and tombstones. Entrance gate in the form of a stylized triumphal arch with three passages ending in an entablature. The inscription on the entablature in German "Jewish military cemetery". The arch of the entrance ends with a sculptural group - the tablets of the testament to the right and left of which are the lying lions. The fence of the cemetery looks light and openwork wooden construction. The fence together with the gate is made in Art Nouveau style. Behind the fence we see rows of graves that are located parallel to the fence. On the graves are matzevot in the form of vertically elongated pillars of the same shape, decorated with the Star of David. The gate and fence are also decorated with the stars of David.

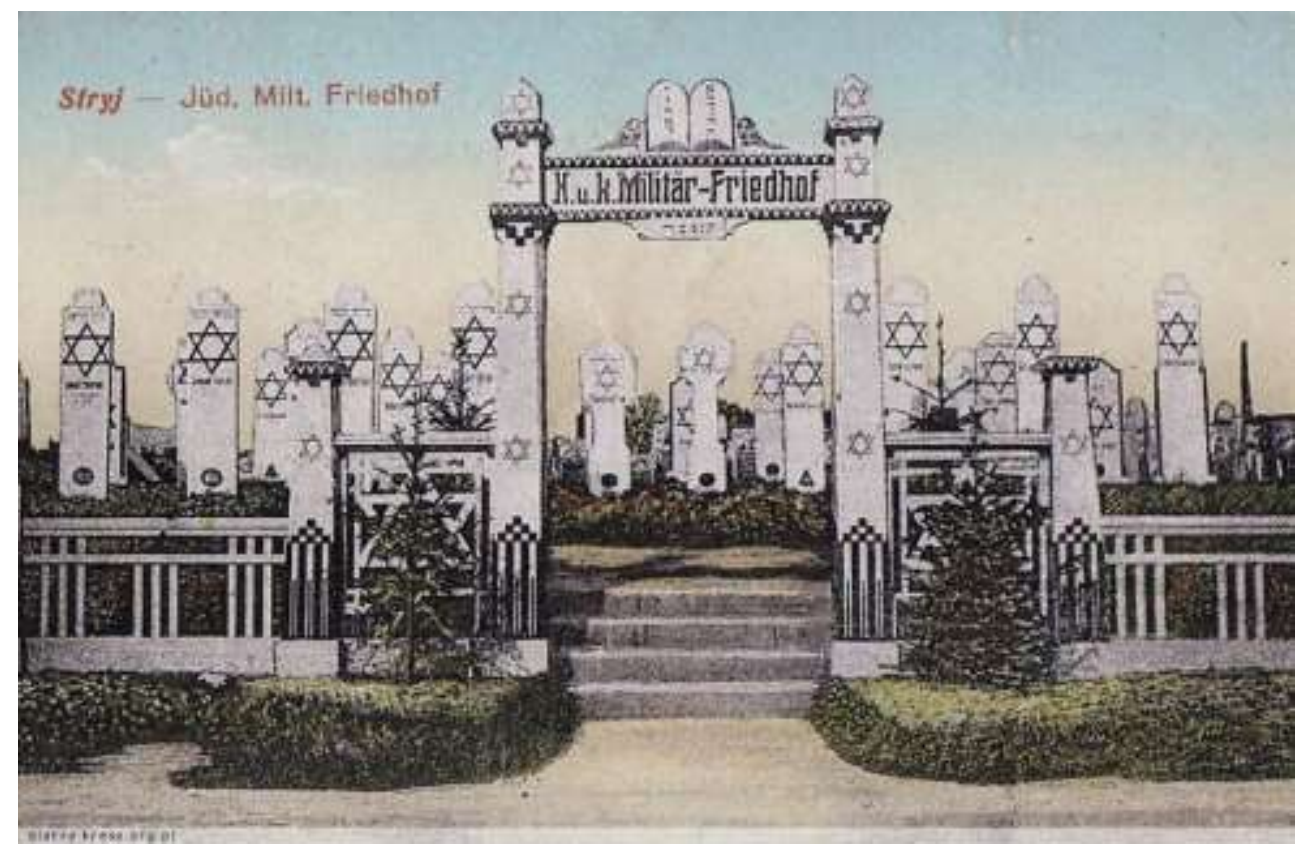

Fig. 8 Jewish military cemetery in Stryi. Postcard from the First World War

\section{Conclusions}

Military cemeteries are a very important and very bright part of the memory of the people, society, state. In fact, they were invented in order to preserve the memory of the fallen heroes, as well as their deeds. The history of military cemeteries is a little over a hundred years old. It's not so much .. During this time on the land where we live today in Galicia swept two world wars and changed four states. It's a lot. States with different languages, different ideologies, philosophy and purpose. Each of these states built its own history, asserted its ideology and tried to emphasize their victories and cover up defeats. And these victories and defeats were very clearly visible in the military pantheon.

So there are enough military cemeteries on this earth. When we talk about non-Christian military cemeteries, they are cemeteries exclusively from the First World War. During the Second World War and in Soviet times, many cemeteries were destroyed. During the Ukrainian state, the destroyed military cemeteries were rebuilt as much as possible. This applies in particular to Turkish military cemeteries. Unfortunately, no surviving Jewish military cemetery could be found on the territory of modern Ukraine. 
As for the current situation, it can be described as satisfactory. Military cemeteries from the First World War require constant care and attention. They are destroyed under the influence of natural factors. It is worth considering the possibility of giving such objects the status of a monument. It is necessary to consider ways of marking non-existent, ie destroyed cemeteries of the First World War, for example, the installation of memorial signs, perhaps using some other ways to restore and the return of our memory.

References
Andrushko, I. 2016. Turks at the front in Galicia [online] Avialiable at: <http://zbruc.eu/node/53876>

Bałaban M. 1909. Dzielnica żydowska. Jej dzieje i zabytki. Lwów : nakładem Towarzystwa Miłośników Przeszłości Lwowa.

Borg A. 1991. War Monuments, London: Leo Cooper

Erickson, E. 2001. Order to Die: A History of the Ottoman Army in the First World War. Greenwood Publishing Group, p. 265

Helston, J., 1998. Jewish necropolis in Lviv. The Galician Gate, 1

Hrankin, P., 1999. From the history of the military cemeteries of Lviv (1914 -1918). The Galician Gate, 5-6

Kharchuk, K., 1999. The Austrian military cemetery and the burial of Ukrainian shooters at Lychakiv. The Galician Gate, 5-6

Partridge, A., 2005. Otwórzcie bramy pamięci. Cmentarze wojenne z lat 1914 - 1918 w Małopolsce. Kraków: Lettra-Graphic.

State Archives of the Lviv Region (SALR), 1922. Plan of the Jewish military cemetery in Lviv. F. 1 (Lviv Voivodeship Administration 1921-1939. Construction Department with thematic and local catalog), op. 30, file no. 4489.

Płomieńczyk, A., 1916. Armya Austro-Wegierska. Warszawa: Wydawnictwo Polskkiej Organizacji Wojskowej.

Schall, J., 1934. Historia Żydów w Polsce, na Litwie i Rusi. Lwów, s.201

Олена Стасюк

Доцент кафедри Архітектури та Реставращії Національний .університет «Львівська Політехніка»

email: olena.stasyuk@gmail.com

ORCID: 0000-0002-2986-6321

\title{
NON-CHRISTIAN MILITARY CEMETERIES OF GALICIA
}

\author{
НЕ ХРИСТИЯНСЬКІ ВІЙСЬКОВІ ЦВИНТАРІ ГАЛИЧИНИ
}

(C) Стасюк O., 2020.

Анотація: У статті проаналізовано юдейські та мусульманські військові цвинтаря, які зустрічаються в Галичині, їх історію, види, форми, та стан збереження. Запропоновано превентивні міри для збереження історичних не 
християнських військових цвинтарів. Історичні цвинтарі є невід'ємною складовою частиною культурного пейзажу кожного міста чи містечка, свідченнями ідеології і духовного жсиття свого часу. Військові цвинтарі можсливо с не в кожному населеному пункті, проте вони дуже чітко фіксують свій час, історію, ідеологію. Надзвичайно важсливі моменти для краӥни і суспільства. Перші військові цвинтарі появляються на Галичині під час першої Світової війни. Причому напередодні Першої світової війни не було традицій національного вщанування великих жертв війни. Військові цвинтарі Першої світової війни являли собою важсливі меморіальні місця даного конфлікту. Юдеї були громадянами Австрійської держави і служба в армї̈ була їхнім обов'язком. Турецькі військові як союзники брали участь у бойових діях на галицькому фронті. Це складає одну з особливостей військових цвинтарів Галичини.

Незалежно від статусу цвинтаря в абсолютно ідеальному стані об'єктів на Україні нема. Кожен цвинтар вимагає безупинного догляду і впорядкування. На військові цвинтарі неухильно накладається ідеологічна складова, щчо ускладнює їх існування. До часів першої Світової війни в Свропі не створювали військових цвинтарів. Саме I Світова війна спровокувала потребу закладання військових цвинтарів в нашій георрафічній широті. Під час цієї війни солдати гинули в небачених досі кількостях. Війна заторкнула всіх. Про неї широко писали газети, розказували очевидці. Не було родини, яка не понесла втрат впродовж цієї війни. В багатьох країнах назріла потреба віддати иану загиблим.

Військові цвинтарі в Галичині були створені під час воснних дій в $1914-1918$ роках. В ситуації матеріальної кризи і загальної непевності щцодо подальщих результатів війни. Було задумано, що ці поховання стануть свосрідною пропагандою, сконсолідують народи і суспільства довкола Габсбурського трону. Вони повинні були стати матеріальним доказом піклування держсави про тих, які не повернулися до дому.

Тут треба зауважнти, що у бойових діях на галицькому фронті брали участь Турецькі військові. Вони проявили себе як хоробрі воӥни, хоча їхні втрати були дуже великими. Багато поранених у бою турків померло в госпіталях Львова, Кракова та Відня. Це складає одну з особливостей військових цвинтарів Галичини. Вцілілі турецькі військові цвинтарі розташовані на околицях сіл Верхня Липиця, Лопушна, Підвисоке, Гутисько та Мечищів. Такожс військові поховання до останнього часу існували в Стрию, Рогатині, Пукові та Путятинцях, де розташовувались військові шпиталі, у яких померла частина поранених солдат Ці солдати були поховані на місцевих кладовищах.

Юдеї були громадянами Австро-Угорської монархії. До 1788 року в АвстроУгорській монархії населення юдейського віросповідання вважалося «не гідним оборонної служби». Однак вже у 1878 році Цісар Йозеф ІІ видає розпорядження в якому говориться, щцо «жиди здатні до військової служби в рядах армії, особливо як водії та каноніри артилерії». Остаточне впорядкування справ, що стосувалися військової служби в Габсбурзькій монархії наступило в 1868 році коли було введено постанову про загальну військову службу. В кінці 1915 року при Військовому Міністерстві був створений Відділ Військових Могил. Відділ Військових могил в Кракові за три роки з 1915 по 1918 запроектував $і$ збудував 400 військових цвинтарів. Серед збудованих цвинтарів і військових полів було 14 цвинтарів воӥнів 
юдейського віросповідання. Місця поховань воӥнів юдейського віросповідання в західній Галичині знаходилися в Яслі, Ольпінах (знищений під час II Світової війни), Б”счі (знищений під час II Світової війни), Грибові, Буровій, Тухові (знищений під час II Світової війни), Тарнові, Бреску, Заклічині, Бохні, Мислєнічах, і в Кракові, у Львові і в Стрию. Нажсаль не вдалося знайти на території сучасної Украӥни жодного збереженого юдейського військового цивнтаря.

Військові цвинтарі є дуже важливою $і$ дуже яскравою частиною пам'яті народу, суспільства, держави. Властиво вони і були придумані для того, щоб зберегти пам'ять про загиблих героӥв, а також про їх вчинки. Щодо існуючого стану, то його можна охарактеризувати, як задовільний. Військові цвинтарі часів Периої світової війни вимагають безперервного догляду $і$ піклування. Вони нищаться під впливом природніх факторів. Варто продумати можсливість надання таким об'єктам статусу пам'ятки. Необхідо продумати способи ознакування, неіснуючих тобто знищених цвинтарів часів I Світової війни, наприклад встановлення пам'ятних знаків можливо якихось інших способів відновлення і повернення нашої пам'яті.

Ключові слова: військовий цвинтар, ,меморіальна пластика, реставрація, камінь. 